\title{
Plasma Cytokine Levels in Migrajneurs During and Outside of Attacks
}

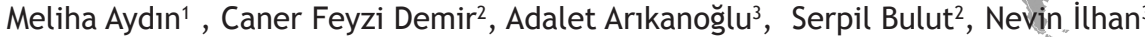

\begin{abstract}
The hypothesis of cytokines as possible pain mediators in neurovascular inflammation offers a potential mechanism for the generation of migraine pain, but few studies examined cytokine levels in migraine patients. The aim of this study was to determine the levels of TNF- $a, I L-4, I L-5, I L-6, I L-10$, and IFN-y in serum of patients with migraine during attacks and attack-free periods. We evaluated 70 patients with migraine. Patients ranged in age from 17 to 5519 healthy people without any diagnosis of migraine or headache were used as a control group. Levels of TNF-a, IL-4, IL-5, IL-6, IL-10, and IFN- $\gamma$ in plasma samples were determined by enzyme-linked immunosorbent assay (ELISA) techniques. The patients were classified as migraine with aura during attack, migraine with aura outside attack, migraine without aura during attack, migraine without aura outside attack according to migraine form presentation. TNF-a levels in migraine patients were significantly higher than in healthy controls. There was a significant change in serum TNF-a levels in patients with migraine with aura during migraine attacks. The levels of IL-6 high in all migraine subgroups compared to controls. In ictal groups, IL-10 levels were found higher than in interictal groups and healthy controls $(p<0.05)$. Changes of the level of TNF- $a, I L-6$ and IL-10 in the blood of patients with migraine may suggest that neurogenic inflammation participates in the pathogenesis of migraine.
\end{abstract}

Key words: Cytokine, migraine, attack

\section{Migrenli Olgularda Atak ve Ataklar Arası Dönemde Serum Sitokin Düzeyleri \\ ÖZET}

Migren ağrısının ortaya çıkmasında muhtemel mekanizma olarak düşünülen nörojenik inflamasyonda sitokinler olası ağrı mediatörleri olarak sunulmuștur fakat migrenli hastalarda sitokin düzeyini inceleyen az sayıda çalıșma bulunmaktadır. Bu çalısmann amacı migrenli hastalarda serum TNF--a, IL-4, IL-5, IL-6, IL-10 ve IFN-y'nın atak ve ataklararası dönemdeki düzeylerini belirlemektir. Migren tanılı 70 hasta değerlendirildi. Hastaların yasları 17 ile 55 yıl arasında idi. Kontrol gurubu olarak yaş ve cinsiyet açısından benzerlik gösteren baş ağrısı veya migren tanısı olmayan sağlıklı gönüllülerden olusan 19 kisi alındı. Çalısmada TNF-a, IL-4, IL-5, IL-6, IL-10 ve IFN-y düzeyleri ELISA yöntemi kullanılarak değerlendirildi. Hastalar migren sinıflamasına göre auralı ( atak ve atak dıșı) ve aurasız (atak ve atak dıșı) olarak sınıflandırıldı. TNF- a, düzeyleri migren subgruplarında sağlıklı kontrol grubuyla karșılaștırıldığında anlamlı derecede yüksekdi. Ayrıca auralı migren hastalarında atakta serum TNF-a düzeyleri diğer subgruplara nazaran belirgin yüksekti. IL-6 düzeyleri kontrol grubuyla karșılaștırıldığında tüm migren subgruplarında yüksekti. Atak gruplarında IL-10 seviyeleri, kontrol grubu ve ataksız gruplarla kıyaslandıgında daha yüksek bulundu ( $p<0.05)$. TNF- a, IL-6 ve IL-10 düzeylerindeki degisiklikler migren patogenezine nörojenik inflamasyonun eșlik ettiğinin göstergesi olabilir.

Anahtar Kelimeler: Sitokin, migren, atak ${ }^{1}$ Department of Neurology, Șifa Medical Center Basmane, Izmir, ${ }^{2}$ Department of
Neurology, Firat (Euphrates) University, Elazig, ${ }^{3}$ Department of Neurology, Dicle
University, Diyarbakir, ${ }^{4}$ Department of Biochemistry, Firat (Euphrates) University,
Elazig, Turkey

Received: 08.03.2013, Accepted: 03.12.2014
Correspondence: Adalet Arikanoglu, Assistant Professor, Dicle University Faculty of Medicine, Department of Neurology 21280, Yenisehir, Diyarbakir-Turkey

Telephone: $+904122488001(4706) \quad$ Fax: +904122488523

E-mail:dradalet23@gmail.com 


\section{INTRODUCTION}

Research on pathophysiological mechanisms of migraine have succeeded in elucidating many of the mechanisms of headache and identifying the involvement of trigeminovascular system. Migraine is a neurovascular disease in which a genetic disposition makes the brain of patients susceptible to a series of endogenous and exogenous trigger factors.

Migraine headache occurs as a result of neuronal-vascular chain of events in which genetic predisposition makes the brain of patients susceptible to a series of endogenous and exogenous trigger factors (1). Headache pain in migraine attack depends on the activation of trigeminal afferents. Recent studies describe an association between migraine and specific immune molecules such as complements and interleukins. Thus, cytokines such as interleukin-2 (IL-2), IL-4, IL-6, IL-10, interferon gamma (IFN- $\gamma$ ), and granulocyte-macrophage colony-stimulating factor (GM-CSF) are proposed to have a relationship with migraine pathogenesis (2). The known high rates of comorbidity between migraine and atopic diseases such as eczema and asthma is an important argument for a suspected immune system dysfunction in migraineurs (3). However, the results of animal studies using nonsteroid anti-inflammatory drugs for inhibition of dural neurogenic plasma protein extravasation, also provide an evidence of the role of meningeal neurogenic inflammation in migraine $(4,5)$. Cytokines are important mediators of the immune and inflammatory pathways and their receptors are widely expressed in the central nervous system; however, there are few studies evaluating cytokine levels in migraineurs (3).

In this study, we aimed to investigate the contribution of cytokines in migraine pathogenesis by evaluating plasma TNF-a, IL-4, IL-5, IL-6, IL-10, and IFN- $\gamma$ levels in migraineurs during and outside of attacks.

\section{MATERIALS AND METHODS}

A total of 70 migraine patients, between 17 and 55 years of age were recruited from the neurology outpatient clinics, headache specialty clinics, and emergency department of Firat University Medical Centre. The control group consisted of 19 healthy volunteers matched for sex and age. Patients were eligible for inclusion if they had at least a 6 month history of moderate or severe migraine attacks. Patients were healthy except for the headaches.
Patients were diagnosed with migraine without aura (MO) or migraine with aura (MA) according to ICHD-II (The International Headache Classification). Patients who had a history of drug use for migraine prophylaxis within the past 3 months, as well as those who had an acute or chronic systemic disease, allergic and autoimmune diseases, or history of chronic drug use, were excluded from the study. Approval was obtained from the local ethics committee and written informed consent was obtained from each patient before the study.

\section{Study design}

On arrival, their medical history, a physical and neurological examination, and electrocardiogram were recorded and routine blood laboratory tests were taken. Thereafter, venous blood specimen of $8 \mathrm{cc}$ was collected from the forearm of the patients, centrifuged at $2000 \mathrm{xg}$, and stored at $-80^{\circ} \mathrm{C}$ until the date of analysis. The measurements were carried out by ELISA (Enzymelinked immunosorbent assay) method. The values measured by a 2005 model Triturus micro ELISA device (Grifols Diagnostic, Spain) using Biosource kits were recorded in $\mathrm{pg} / \mathrm{mL}$.

\section{Statistical Analysis}

Statistical analyses were performed by SPSS 12.0 package program. The results were expressed as mean \pm standard deviation (SD) values. Intergroup comparisons were carried out by Mann-Whitney $U$ test. A $p$ value $<0.05$ was recognized as statistically significant.

\section{RESULTS}

Patients were classified into 4 groups. First group included 15 patients with migraine with aura during attack (MAictal), second group included 15 patients with migraine with aura outside attack (MA-interictal), third group included 20 patients with migraine without aura during attack (MO-ictal), and fourth group included 20 patients showing migraine without aura outside attack (MOinterictal). Nineteen age- and gender-matched healthy individuals were enrolled as the control group. Female/ male ratio of the study groups was $49 / 21$, it was $14 / 5$ in the control group $(p>0.05)$. The age of the patients varied between 17-55 years and mean age was calculated for each group. The mean age of the controls was 33 years ( $p>0.05$ ). Age and gender distribution of the study and control groups are shown in the Table 1. 
Table. Demographic characteristics of patient and control groups included in the study

\begin{tabular}{|c|c|c|c|c|c|c|}
\hline & & MA-ictal & MA-interictal & MO-ictal & MO-interictal & Control \\
\hline \multirow{3}{*}{$\begin{array}{l}\text { Age } \\
\text { Sex }\end{array}$} & & $35.85 \pm 3.0$ & $31.62 \pm 1.2$ & $34.20 \pm 2.1$ & $35.36 \pm 3.3$ & $33.13 \pm 2.8$ \\
\hline & Female & 11 & 11 & 13 & 14 & 14 \\
\hline & Male & 4 & 4 & 7 & 6 & 5 \\
\hline
\end{tabular}

Serum TNF-a levels were as follows; MA-ictal, 1.948 \pm 0.710 ; MA-interictal, $1.521 \pm 0.555$; MO-ictal, $1.276 \pm 0.564$, MOinterictal, $1.541 \pm 0.481 \mathrm{pg} / \mathrm{mL}$. The control group had a serum TNF-a level of $0.895 \pm 0.520 \mathrm{pg} / \mathrm{mL}$. There were statistically significant differences between the control group and MA-ictal $(p<0.05), M A$-interictal $(p<0.05)$, and MO-interictal $(p<0.05)$. Although MO-ictal exhibited higher TNF-a levels compared with the control group, but the difference was not statistically significant. When the study groups were compared with each other instead of the control group, a statistically significant difference was determined between MA-ictal and MO-ictal $(p<0.05)$. (Figure 1)

Serum IFN- $\gamma$ levels were as follows; MA-ictal, 20.206 \pm 5.284 ; MA-interictal, 18.765 $\pm 7.500 ;$ MO-ictal, $18.346 \pm 7.780$; MO-interictal, $19.444 \pm 6.559 \mathrm{pg} / \mathrm{mL}$. The control group had a IFN- $\gamma$ level of $19.213 \pm 6.635 \mathrm{pg} / \mathrm{mL}$. There was no statistically significant difference between the migraine groups and the control group.

Plasma concentration of IL-4 was $2.324 \pm 0.343 \mathrm{pg} / \mathrm{mL}$ in the control group, while it was $2.310 \pm 0.416,2.294 \pm 0.310$, $2.161 \pm 0.314$, and $2.291 \pm 0.332 \mathrm{pg} / \mathrm{mL}$ in MA-ictal, MA-

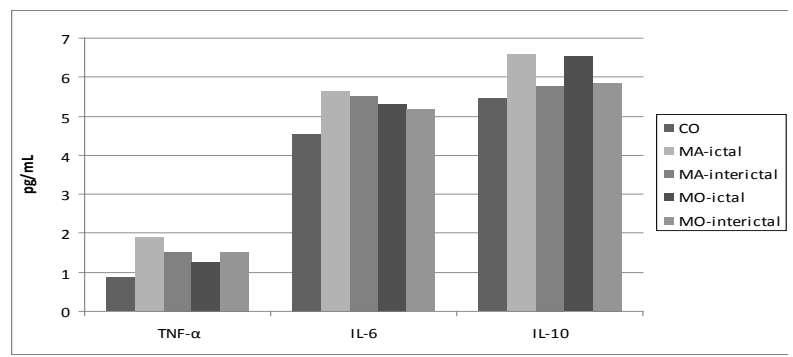

Figure. IL-10, IL-6, TNF-a levels in MA-ictal, MAinterictal, MO-ictal, MO-interictal and control group

${ }^{*} p<0.05$ when compared with control group, ${ }^{* *} p<0.01$ when migraine groups are compared with each other

MA-ictal; migraine with aura during attack, MA-interictal; migraine with aura outside attack, MO-ictal; migraine without aura during attack, MOinterictal; migraine without aura outside attack, CO; control group interictal, MO-ictal, MO-interictal groups, respectively. No statistically significant difference was determined between the groups. Plasma concentration of IL- 5 was $3.264 \pm 0.594,3.385 \pm 0.472,3.331 \pm 0.398$, and $3.403 \pm 0.434$ $\mathrm{pg} / \mathrm{mL}$ in MA-ictal, MA-interictal, MO-ictal, MO-interictal groups, respectively. In the control group, IL-5 level was $3.276 \pm 0.588 \mathrm{pg} / \mathrm{mL}$. No statistically significant difference was found between the groups.

Plasma concentration of IL-6 was $5.684 \pm 0.917$, $5.542 \pm 1.050,5.321 \pm 0.927$, and $5.182 \pm 0.796 \mathrm{pg} / \mathrm{mL}$ in MA-ictal, MA-interictal, MO-ictal, MO-interictal groups, respectively, whereas it was $4.565 \pm 0.418 \mathrm{pg} / \mathrm{mL}$ in the control group. Plasma IL-6 level was found to be significantly higher in MA-ictal, MA-interictal, and MO-ictal groups compared with the control group. The statistical difference level was $p<0.01$ between MA-ictal and control group, $p<0.05$ between MA-interictal and control group, and $p<0.05$ between $\mathrm{MO}$-ictal and control group. Although MO-interictal had a higher IL-6 concentration compared with the control group, the difference between was not statistically significant. Furthermore, MA-ictal, and MOictal (ictal groups) had higher IL-6 levels compared with MA-interictal, MO-interictal (interictal groups), however, these differences were not statistically significant, as well. Figure.

Plasma concentration of IL-10 in the control group was $5.475 \pm 0.625 \mathrm{pg} / \mathrm{mL}$, whereas it was $6.597 \pm 1.986,5.788 \pm$ $0.590,6.543 \pm 0.871$, and $5.871 \pm 0.756 \mathrm{pg} / \mathrm{mL}$ in $M A$-ictal, MA-interictal, MO-ictal, MO-interictal groups, respectively. Plasma IL-10 level was found to be statistically significantly higher in MA-ictal, and MO-ictal (ictal groups) than in control group $(p<0.05)$, however, although plasma level of IL-10 was also higher in MA-interictal and MO-interictal (interictal groups) than in controls, the differences between were not statistically significant. Similarly, IL-10 levels were higher in MA-ictal, and MO-ictal (ictal groups) than in MA-interictal and MO-interictal (interictal groups), however, the differences were not statistically significant. Figure. 


\section{DISCUSSION}

While previous studies have shown that immune system contributes to the migraine pathophysiology, there have been conflicting study results and no consensus about the mechanism of this contribution. Different studies evaluating serum TNF-a levels in migraineurs have produced very different results. In 1990, Covelli et al. compared cases of migraine without aura with controls and determined an excessive release of TNF-a (6). Gallai et al. conducted a study on migraine patients with magnesium deficiency and found elevated serum IL-1, IL-6, and TNF-a levels (7). Sarchielli et al. determined temporary increases in TNF-a levels in internal jugular blood of $7 \mathrm{pa}$ tients without aura during spontaneous attacks (8). In our study, there was a statistically significant difference with regard to TNF-a levels between the control group and $M A$-ictal, control group and MA-interictal, control group and $\mathrm{MO}$-interictal. MA-ictal displayed a significantly elevated TNF- $\alpha$ level compared with the MA-interictal, MOictal and MO-interictal. This finding was consistent with the studies $(6,8)$ reported in the literature and it was supportive of the opinion that hyperalgesic TNF-a release during a migraine attack contributes to the trigeminovascular hyperstimulation in migraine pathophysiology.

Previous studies evaluating plasma IL-4 levels in migraineurs have provided conflicting results. Martelletti et al. conducted a study on food-induced migraine cases and found that plasma GM-CSF and IFN- $\gamma$ were increased, and IL-4 and IL-6 levels were decreased during attack (9). In cases of isosorbid dinitrate-induced attacks, as in cases of spontaneous migraine, plasma IL-4 levels appear to be low (10). In their first study, Munno et al. determined elevated IL- 4 and IL- 5 only in some migraine cases (11), however, in their following study, they found immeasurably low plasma IL-4 and IL-5 levels in migraine patients without aura during attack. In the same study, following sumatriptan therapy, both cytokine concentrations displayed significant increases (2). In a recent study of Sarchielli et al., IL-4 levels in jugular venous blood showed a decline during attack. Since Th2 cells are a major source of IL-4, authors explained the IL-4 decrease with Th2 inhibition during attack (8). In our study, neither between migraine and control groups nor during attack and outside attack, there was no statistically significant difference in IL-4 levels. The studies we reviewed were based on a single migraine group, evaluating the during or outside migraine attacks. However, generally, slightly elevated IL-4 levels in our migraine groups can be ex- plained with the increasing use of triptan, as well as with differences in methodology and measurements.

IL-6 acts as a mediator in peripheral acute phase response (12). Furthermore, vasodilatation, a characteristic feature of headache phase, contributes to the drop in body temperature during attacks (3). IL-6 also induces hyperalgesia $(13,14)$. Sarchielli et al. found raised IL-6 levels in internal jugular blood during the early hours of attack among cases of migraine without aura (8). Gergont et al. determined high IL-6 concentrations within the first hour of a migraine attack in children (15). Fidan et al. reported significantly higher serum IL-6 levels during attacks and interictals in migraine patients compared with the healthy controls (16). Marteletti et al. determined reduced IL-6 levels during attack in food-induced migraine cases (9). Munno et al. reported that, similar to cytokines associated with allergic inflammation including IL-4 and IL-5; IL-10 expression by antigen-presenting cells can contribute to the alleviation of inflammation by its ability to inhibit the synthesis of non-specific proinflammatory cytokines similar to IL-1, IL-6, and TNF-a (2). In our study, serum IL-6 levels in MA-ictal, MA-interictal and $\mathrm{MO}$-ictal were significantly higher than in controls. These results were consistent with some of the literature reporting significant differences between migraine patients and healthy individuals with regard to IL-6 levels. This increase in IL-6 level which has an important role as a proinflammatory cytokine, supports the opinion advocating involvement of neurogenic inflammation in migraine pathogenesis.

In our study, serum IL-10 levels were higher in interictal (outside attack) groups than in controls, the differences were not statistically significant. Similarly, IL-10 levels were higher in ictal groups than in interictal groups, however, the differences were not statistically significant. There are only a few reports about the role of IL-10 in migraine. IL-10 is also described as an inhibitor of cytokine synthesis. This result is consistent with the study of Munno and colleagues $(2,11)$ and the study of Fidan et al. who reported increases in serum IL-10 levels during attack (ictal period) (16). Owing to the anti-inflammatory properties of IL-10, the increase in IL-10 levels during attacks has been proposed to be a reaction against some proinflammatory cytokines released throughout the active headache period (2). On the contrary, same patients exhibited a decrease in plasma IL-10 levels and an increase in plasma IL- 4 and IL- 5 levels following sumatripan therapy which acts via 5HT1D receptors. Therefore, su- 
matripan therapy is noted to restore the cytokine profile observed during the interictal period (11). The elevated IL-10 level during migraine attack can be understood as a response aiming to balance the increased level of plasma proinflammatory cytokines during attack.

IL-5 stimulates proliferation and differentiation of B cells and eosinophils (17). The number of studies on IL-5 levels in migraine is limited. Munno et al. performed the first study in this subject and reported raised IL-5 levels in some cases (11), however, in their following studies, they also noted immeasurably low IL-5 concentrations in cases of migraine without aura during attack (2). We did not observe a significant difference between plasma IL-5 levels of migraine patients with and without aura during attack and interictal.

The studies of serum IFN- $\gamma$ levels in migraine are consistent with each other. Most of the studies report no changes in IFN- $\gamma$ levels during attack and interictal periods of migraine patients $(11,16)$. Only Marteletti et al. reported an elevated plasma IFN- $\gamma$ level in food-induced migraine cases during attack (9). In our study, consistent with most of the studies in the literature, no difference was determined between the study and control groups with regard to IFN- $\gamma$ level.

The studies aimed to determine cytokine levels in migraine, have produced contentious results. Exact time of the day when the specimens are obtained during attack, appears to be an important factor affecting the meassurement values, because some hormones are well known to have diurnal rhythm. Particularly, the diurnal rhythm of cortisol should be borne in mind when evaluating the immune status of migraine patients. In this study, we were able to collect blood specimens upon presentation of migraine patients to the hospital during attack or interictal periods. It was not possible to perform a standardization relative to the onset of attacks or duration of the previous attack. Furthermore, failure to apply repeated measurements at different time points during attack or interictal, and non-exclusion of factors such as fasting and insomnia which could have an influence over cytokine release, appear to be the other limitations of our study. Another limitation of these measurements is to detect real change in the levels of cytokines, because of their short serum half-life and fast degradation and excretion.

In conclusion, the results acquired from this study supports the opinion advocating that immune system is in- volved in migraine. Furthermore, our results reveal that this immune involvement may be associated with characteristic clinical changes in migraine subgroups. Any differences noted would expand and clarify a neuroimmune hypothesis of migraine pathogenesis and lead to future diagnostic markers or therapeutic options or both for migraine. Determination of the prominent cytokine profiles in ictal and interictal periods may allow us to consider more satisfactory agents in terms of efficacy and side effects.

\section{REFERENCES}

1. Aggarwal1 M, Puri $V$ and Puri S. Serotonin and CGRP in Migraine. Ann Neurosci 2012;19: 88-94.

2. Munno I, Marinaro M, Bassi A, et al. Immunological Aspects in Migraine: Increase of IL-10 Plasma Levels During Attack. Headache 2001;41:764-7.

3. Kemper RHA, Meijler WJ, Korf J, et al. Migraine and function of the immune system: a meta-analysis of clinical literature published between 1966 and 1999. Cephalalgia 2001; 21: 549-57.

4. Buzzi MG, Sakas DE, Moskowitz MA. Indomethacin and acetylsalicylic acid block neurogenic plasma protein extravasation in rat dura mater. Eur $J$ Pharmacol 1989;165(2-3):251-8.

5. Levy D. Endogenous mechanisms underlying the activation and sensitization of meningeal nociceptors: the role of immuno-vascular interactions and cortical spreading depression. Curr Pain Headache Rep 2012; 16 :270-7.

6. Covelli V, Munno I, Pellegrino NM, et al. Exaggerated spontaneous release of tumor necrosis factor-alphacachectin in patients with migraine without aura. Acta Neurol (Napoli) 1990; 45:257-63.

7. Gallai V, Sarchielli P, Franceschini M, et al. Is magnesium deficiency involved in the cytokine/neurogenic inflammation in migraine? Headache 1994; 34:297-8.

8. Sarchielli P, Alberti A, Baldi A, et al. Proinflammatory cytokines, adhesion molecules, and lymphocyte integrin expression in the internal jugular blood of migraine patients without aura assessed ictally. Headache 2006;46(2):200-7.

9. Martelletti $P$, Stirparo $G$, Rinaldi $C$, et al. Disruption of the immunopeptidergic network in dietary migraine. Headache 1993; 33:524-7.

10. Martelletti P, Stirparo G, Morrone S, et al. Inhibition of intercellular adhesion molecule-1 (ICAM-1), soluble ICAM1 and interleukin- 4 by nitric oxide expression in migraine patients. J Mol Med (Berl) 1997;75(6):448-53.

11. Munno I, Centonze V, Marinaro M, et al. Cytokines and migraine: increase of IL-5 and IL-4 plasma levels. Headache 1998;38(6):465-7.

12. Uzar E, Evliyaoglu $O$, Yucel $Y$, et al. Serum cytokine and pro-brain natriuretic peptide (BNP) levels in patients with migraine.Eur Rev Med Pharmacol Sci 2011;10:1111-6. 
13. Obreja O, Biasio W, Andratsch M, et al. Fast modulation of heat-activated ionic current by proinflammatory interleukin 6 in rat sensory neurons. Brain 2005;128:1634-41.

14. Oka Y, Ibuki T, Matsumura K, et al. Interleukin-6 is a candidate molecule that transmits inflammatory information to the CNS. Neuroscience 2007;145:530-8.

15. 15. Gergont A, Kacinski M, Kwinta P. Proinflammatory cytokines in children with idiopathic headache. Przegl Lek 2005;62:1269-75.
16. Fidan I, Yüksel S, Ymir T, et al. The importance of cytokines, chemokines and nitric oxide in pathophysiology of migraine. J Neuroimmunol 2005;30:184-8.

17. Baumann MA, Paul CC. Interleukin-5 and human B lymphocytes. Methods 1997;11:88-97. 